\title{
E-government learning media through augmented reality technology
}

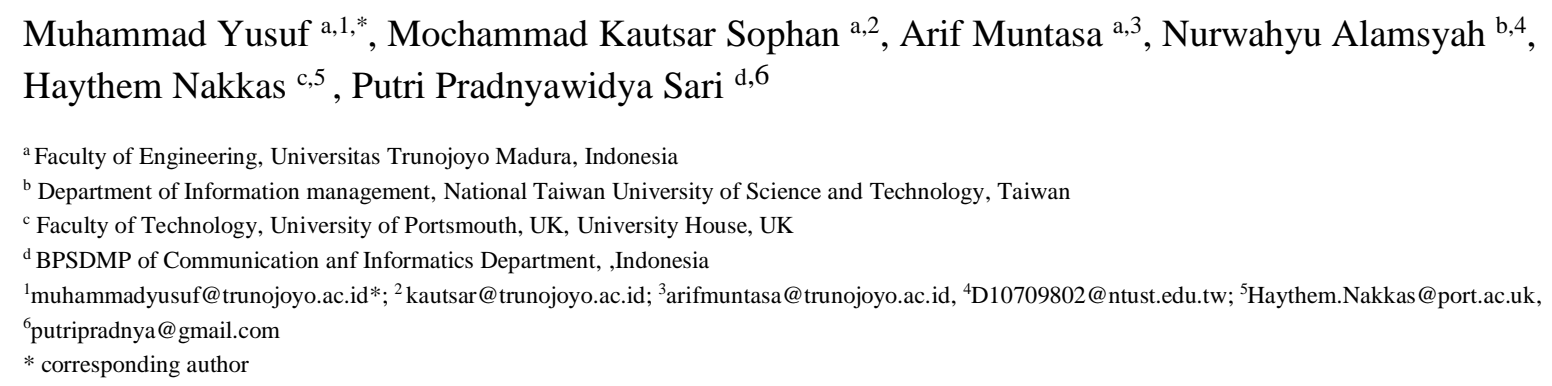

Article history

Received January 2, 2020

Revised January 16, 2020

Accepted February 1, 2020

Keywords

E-Government

Learning media

Augmented reality

Technology
ABSTRACT

\begin{abstract}
Augmented reality (AR) is one of the newest learning technologies besides Artificial Intelligent, Virtual Reality, Virtual World, Alternates Reality Games, and Wearable Computing. E-Government is becoming an evolving academic field and transforming to be E-Governance, E-Participation, E-Service, E-Democracy, E-Voting issues. Therefore, some universities have E-Government course in their curriculum. AR can be one of the learning media to learn and teach $\mathrm{E}$ Government effectively and interestingly. This research aims and contributes to develop a novel model of E-Government learning media using AR. Furthermore, this work has three novelties as follows:First, a method to develop e-Government learning media using AR. Second, a novel model of e-government learning media based on augmented reality technology. Third, the material courses are command centre and public service mall materials based in Surabaya, Indonesia. The new model of learning media using AR consists of main components, i.e., user, devices, AR, and course materials. Additionally, this novel model has some sub-components, such as AR object, marker, text, image, audio, video, and 3D animation. The proposed model has some practical and theoretical implications. For the theoretical implication, it adds a model of learning media for egovernment course and extends the body of knowledge for e-government and augmented reality fields. For practice, e-Government courses can uilize the augmented reality application.
\end{abstract}

This is an open access article under the CC-BY-SA license.

\section{Introduction}

Learning media technologies are always improved every time. Augmented reality is one of the emerging technologies which can be used for educational purposes. There are some newest learning technologies, such as Artificial Intelligent, Augment Reality, Virtual Reality, Virtual World, Alternates Reality Games, and Wearable Computing. In other hand, E-Government field keep evolving as many government utilize electronic technology to keep up to date with the advancing in technology and improve the services they provide. Issues in E-Government are also growing, such as E-Governance, E-Participation, E-Service, E-Democracy, E-Voting and others.Some universities provide E-government as part of their courses. E-Government courses uses some traditional learning medias and methods. However, using emerging technologies such as augmented reality would potentially supportE-Government learning. Therefore, augmented reality could help the users or learners to easily understand about the materials of e-Government course. 
However, there is a limited research about use of augmented reality technology in the eGovernment field. Therefore, this research aims to develop a novel model for E-Government learning media through augmented reality technology. In this case, we selected two materials of eGovernment course, i.e. Introduction of Command Centre and Public Service Mall. The case study is E-Government course in Department of Information System at Universitas Trunojoyo Madura, Indonesia. This paper contributes a new model for E-Government Learning media using augmented reality. This work has three novelties as follows: First, a method to develop e-Government learning media using AR. Second, a novel model of e-government learning media based on augmented reality technology. Third, the material courses are command centre and public service mall materials based in Surabaya, Indonesia.

Moreover, this paper consists of introduction, material and methods, theory, results, discussion, and conclusion sections. Introduction section captures background, gap, aim, contribution, and novelties of the research. Material and methods section describes step by step research in flowchart and its description. Theory section explains E-Government and Augmented Reality literature reviews. Results section consists of AR user interface design and the AR system. Discussion section examines analysis, challenges, advantages, and limitations of the AR system for E-Government course teaching. Conclusion section consists of summary, conclusion, implication and future research.

\section{The Proposed Method/Algorithm}

E-Government as Electronic Government or Electronic Governance field emerged in the late 1990's. However, the use of computer for supporting government activities has existed for a long time [1], [2] discussed the trends of E-Government research and its opportunities; [3] evaluated the performance of public services by local government; [4] identified empirical evidences to assessedthe impacts of the decentralisation. Furthermore, it assesed public services Spanish local governments for the quality of life of the citizen; [5] captured ethical concern in public service by local government of pekanbaru city; [6] explored citizen participation in public e-service development. The participation consists of user-centred design, participatory design, and user innovation; [7] examined e-services in the public sector domain by classifying it into three cateories, (a) a service, (b) electronic, and (c) public; [8] discussed the co-evolution of public governance innovation. It also proposed an adoption of Hartley's model, such as co-evolution; [9] identified the role of stakeholders in the effective use of E-Government resources in public services.

There are also some literature about augmented reality, i.e., discuss the impact of AR on student's learning process. This research stated that AR has a medium impact on the learning gains of students[10]; [11] examined AR research trends regarding science education. This research captured mobile learning, science education, science learning, and e-learning as the most popular topics; [12] captured the AR technological acceptance of students, the student performance, and gender factors. This research showed that AR can be employed in a university teaching, and the student's gender does not influence learning; [13] discussed the development of an augmented reality game-based learning environment; [14] examined an AR application to test its feasibility with enhancing the training process, learning time, and error rate. This work highlighted that AR produced better results for error rates and the average assembly times; [15] captured the implementation and evaluation of AR technology for 3D visualization models and architectural projects presentation; [16] discussed enhancing the attractiveness of Learning through AR technology. In this work, the researcher developed four applications to improve communication and collaboration skills as well as biology and geography learning; [17] captured critical success factors and challenges for industrial AR implementation projects. Technology, organisation, environment (TOE) framework is utilized as a theoretical basis for the quantitative method and the questionnaire. A complementary qualitative approach is also employed to analyzed the findings; [18] analyzed the integration of AR into educational in-class activities. AR is utilized to to improve behavioral changes towards energy efficiency in schools; [19] reviewed several literatures of mobile augmented reality and its potentials for education; [20] examined AR experiment in higher education. In this case, AR is employed in pedagogy, but this experience is also important for introducing engineering students about the potential of augmented reality; [21] pointed out AR for education and training to meet the requirements of digitalization in the industrial revolution more successfully. 


\section{Method}

There are some stages for conducting this research as shown in "Fig. 1,". First, we developed a research design of how to develop an e-government learning media based on augmented reality technology. Second, we collected references about learning media using augmented reality in journals, conference proceedings, books, website, youtube, and playstore. We searched references in science direct website using keywords of augmented reality, augmented reality for e-government, and e-government learning. Also, we searched video in youtube and applications in playstore about learning media using augmented reality. From youtube, we found some learning medias in Bahasa, such as virus biology learning, pray and ablution procedures, introduction of earth layers and structures, and introduction of Garuda Pancasila. Third, we conducted user requirement analysis. In this step, we identified hardware, software, and user interface requirements. This AR application needs smartphone, PC, or laptop to run the program. The application also require some softwares, i.e., Unity 2018, SketchUp, Visual Studio 2019, and Paint. Fourth, we designed AR interface and the application. "Fig. 2," shows design of user interface for the AR application. Fifth, we produced a presentation about introduction of command centre and public service mall as shown in "Fig, 4,". These materials will be included in the introduction menu in command centre and public service mall interfaces. Sixth, we recorded the first author to deliver a lecture about introduction of command centre and public service mall. Seventh, we recorded a video of public service mall in real condition as shown in "Fig. 5,". This video was taken at 1st floor of Former Siola Building in Surabaya, Indonesia in the morning. It is one stop shopping for public service in local government of Surabaya, Indonesia. Eighth, we also recorded a video of public service mall in real condition using cardboard camera application as shown in "Fig. 6,". This application is utilized to get virtual reality video. Ninth, we produced a video of command centre. In this step, we captured from youtube and other video sources in the internet as difficult to record in the real command centre. There is a procedure and takes time to get permission for recording the real command centre. Tenth, we developed an E-Government learning media as shown in "Fig. 3,". In this stage, we also created 3D animation for command centre and public service mall as captured in "Fig. 7 and 8,". Additionally, AR objects and markers are also produced in this application. Eleventh, we created markers of command centre and public service mall. Twelfth, we tested and validated the learning media in the course session.

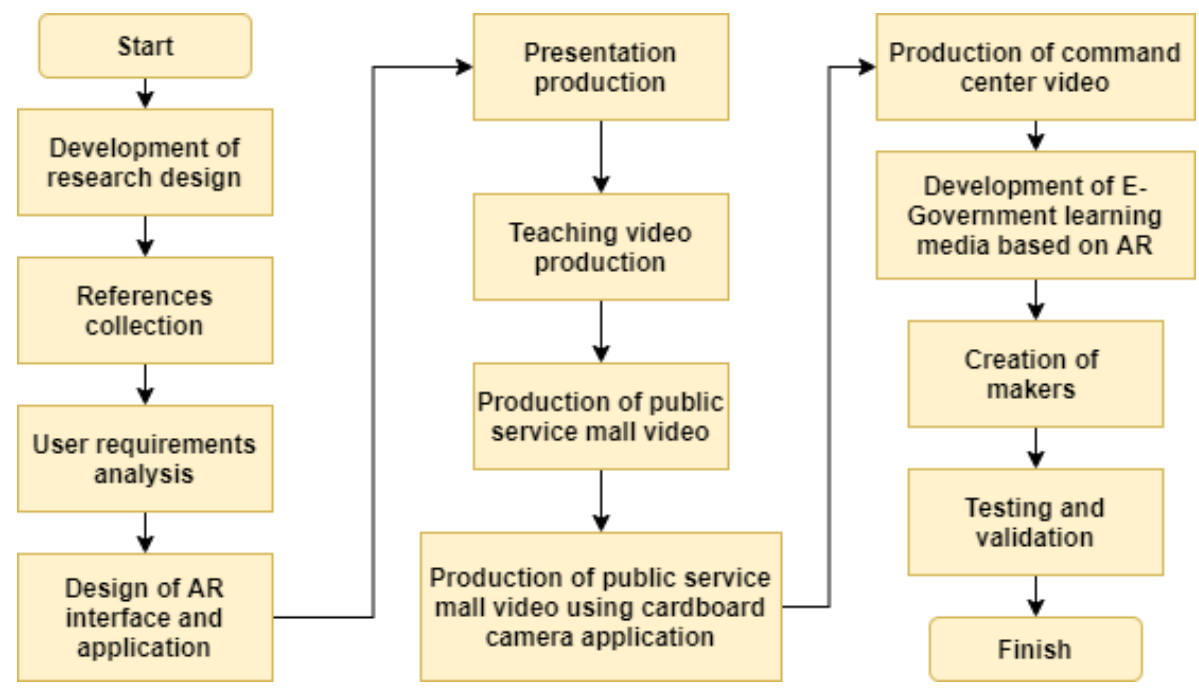

Fig. 1.Step by step research method

\section{Results and Discussion}

In the design process, we set up the user interface as shown in the "Fig. 3,". The first interface contains text to explain the title Teaching Media of E-Government Course, then user can click start button. After that, the second interface will appear consist of two options, i.e., Command Centre and Public Service Mall. User can choose one of them and the third interface will come out. It contains three menus, i.e., Introduction, Video 360, and Augmented Reality. Introduction menu consists of explanation about Command Centre or Public Service Mall, such as definition, objective, 
components, types, and stages. Video 360 menu has content about virtual reality video of command centre or public service mall. This video can be seen using virtual reality glasses or Google card board. Then, user can click augmented reality menu which consist of AR object. This animation object describes staff of command centre or public service mall that can look left and right.
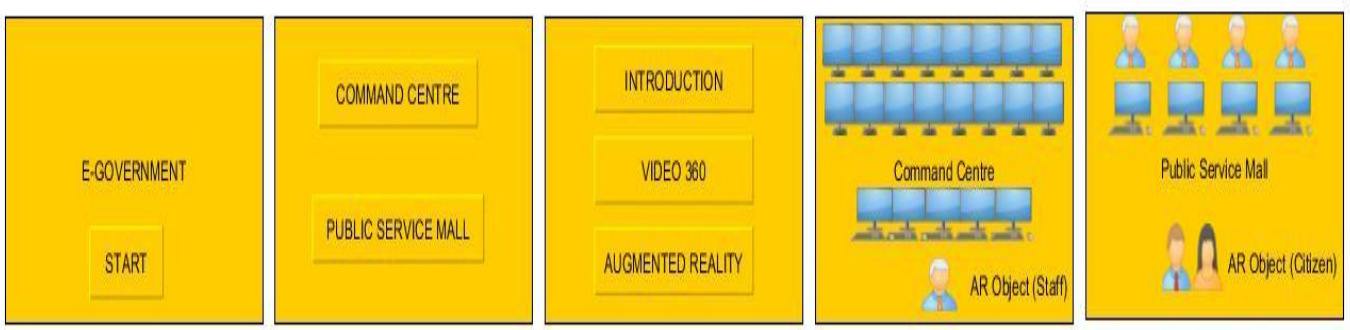

Fig. 2.Design of AR user Interface

Furthermore, "Fig. 3," captures main interface of the AR application. It consists of two main menus, i.e., command centre and public service mall. Therefore, the user can choose one of the menus, then it will goe to the next user interface.

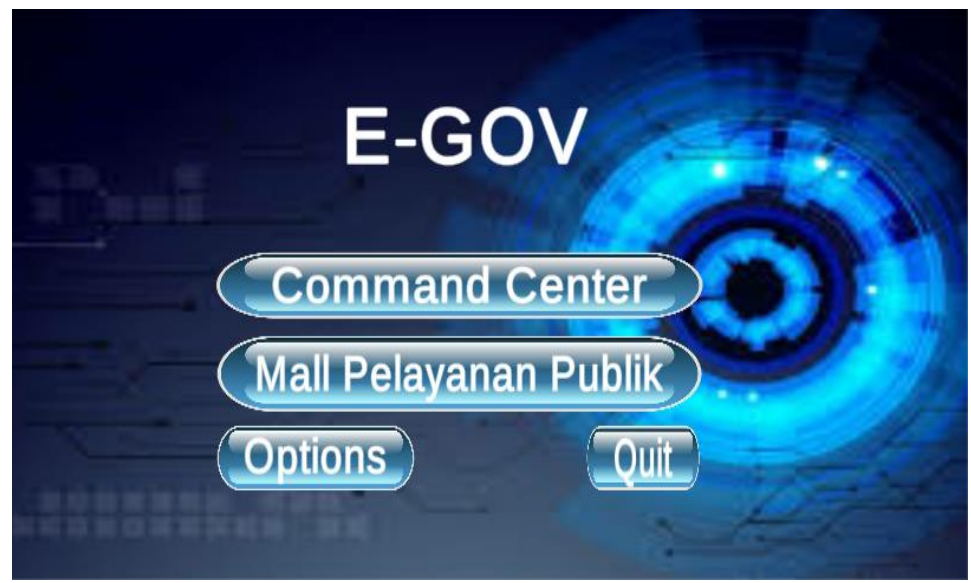

Fig. 3.Main Interface

Moreover, "Fig. 4," shows video of E-Government materials teaching. In the video, the first author delivers a lecture about Introduction of Command Centre and Public Service Mall. The duration of the video is 4 minutes and 14 second. Furthermore, the length of video of public service mall is 3 minutes and 10 second. This video was taken at first author home.

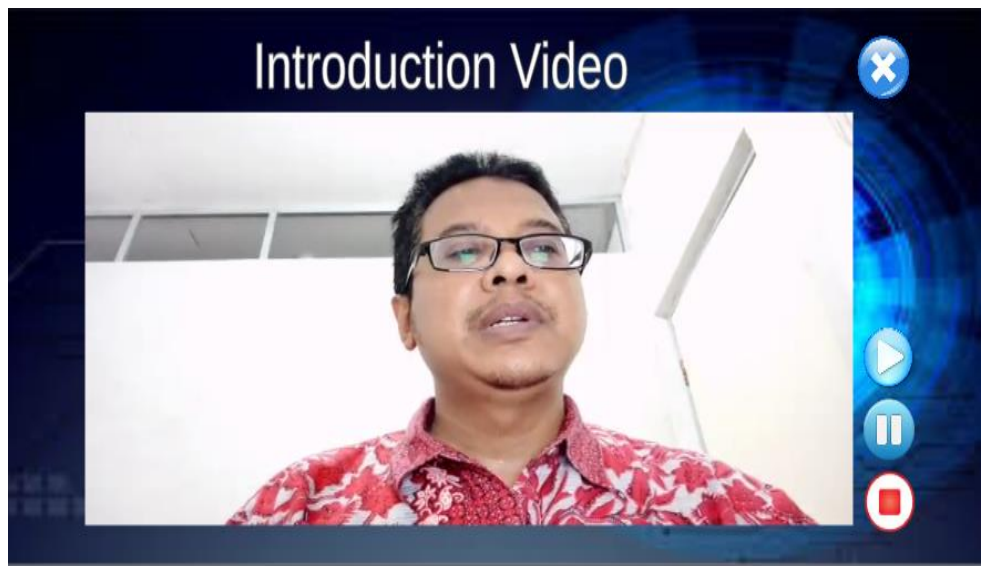

Fig. 4.Video of command centre and public service mall teaching

The next "Fig. 5," is video of public service mall in real condition. In this place, the public service mall opens everyday to serve Surabaya citizen for arranging administration and other public service affairs. 


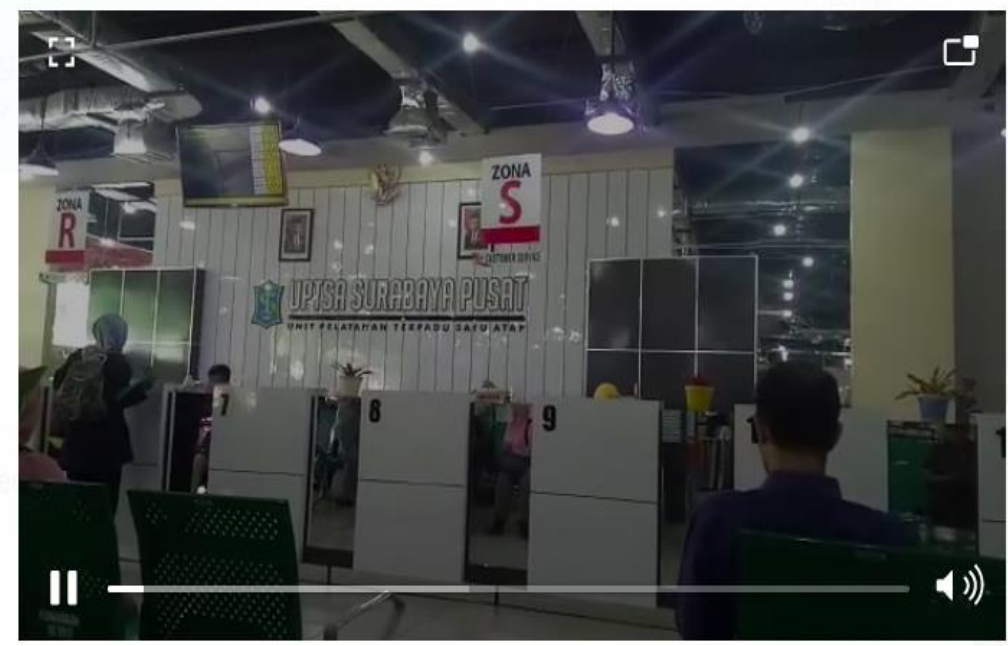

Fig. 5.Video of public service mall in real condition

Moreover, "Fig. 6," points out video of public service mall using cardboard camera application. It is a virtual reality video. User need to wear virtual reality glasses or camera cardboard.

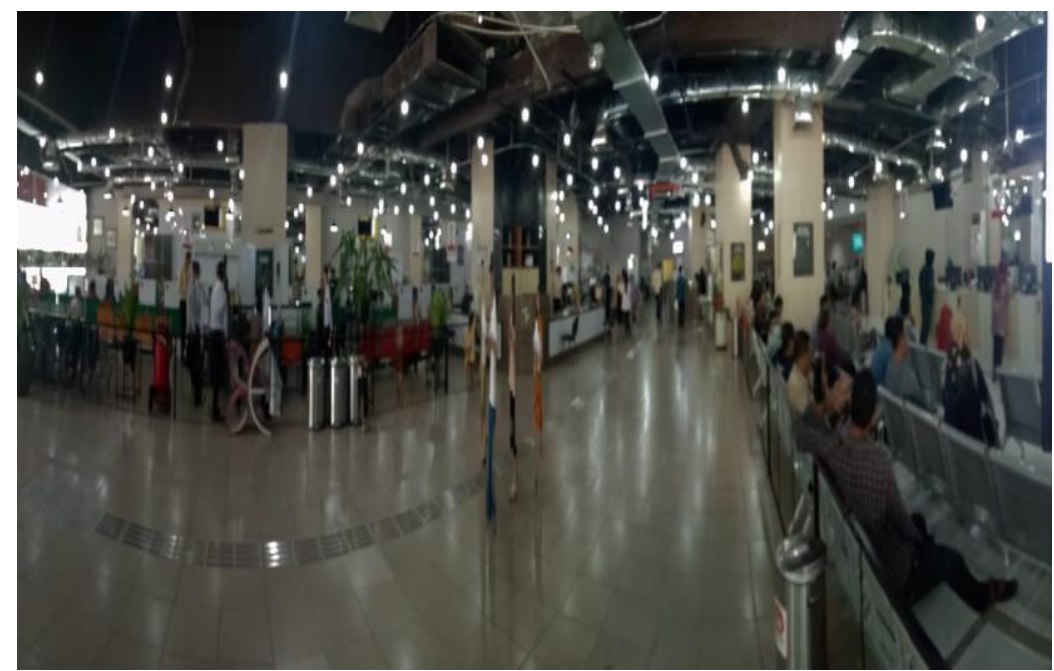

Fig. 6.Video of public service mall using cardboard camera

Additionally, "Fig. 7," captures a video of command centre. This video was captured from youtube and edited by adding voice of second author to explain about command centre.

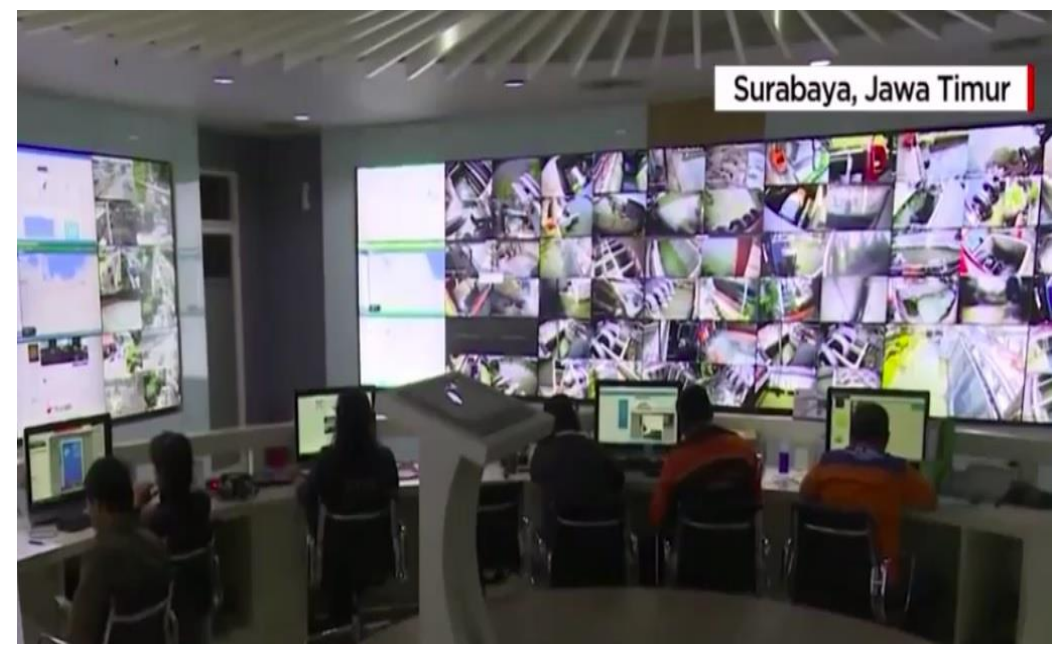

Fig. 7.Video of real command centre 
Then, "Fig. 7," captures animation of command centre. This figure contains computers, desks, and monitor screens. "Fig. 8," shows animation of public service mall. This figure consists of desks, computers and staffs to serve the citizen.

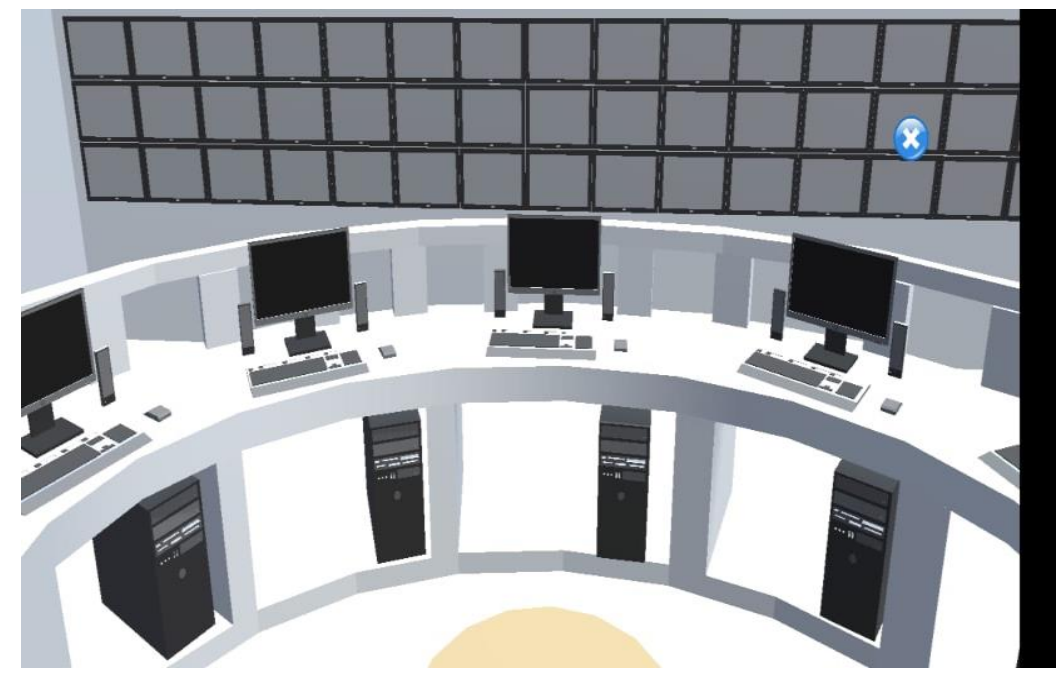

Fig. 8.Animation of Command Centre

Based on our project, we developed a novel model of learning media using AR as shown in "Fig. 9,". This model consists of main components, i.e., user, devices, AR, and course materials. The user can be a student or anyone who has access the AR for to learn about a topic. Devices can be a smartphone, a laptop, and a personal computer. AR consists of object and a marker. In this project, AR objects are command centre and public service mall. Markers are icon, text, image, or something that can be scanned by the devices to detect and get in to the AR object. Then, the user can access the course materials in text, image, video, and audio forms. In this case, the course materials are egovernment materials focusing on introduction of command centre and public service mall "Fig. 10, .

In E-Government lecture, students have to come to the command centre and public service mall building to learn about command centre and public service mall learning materials.

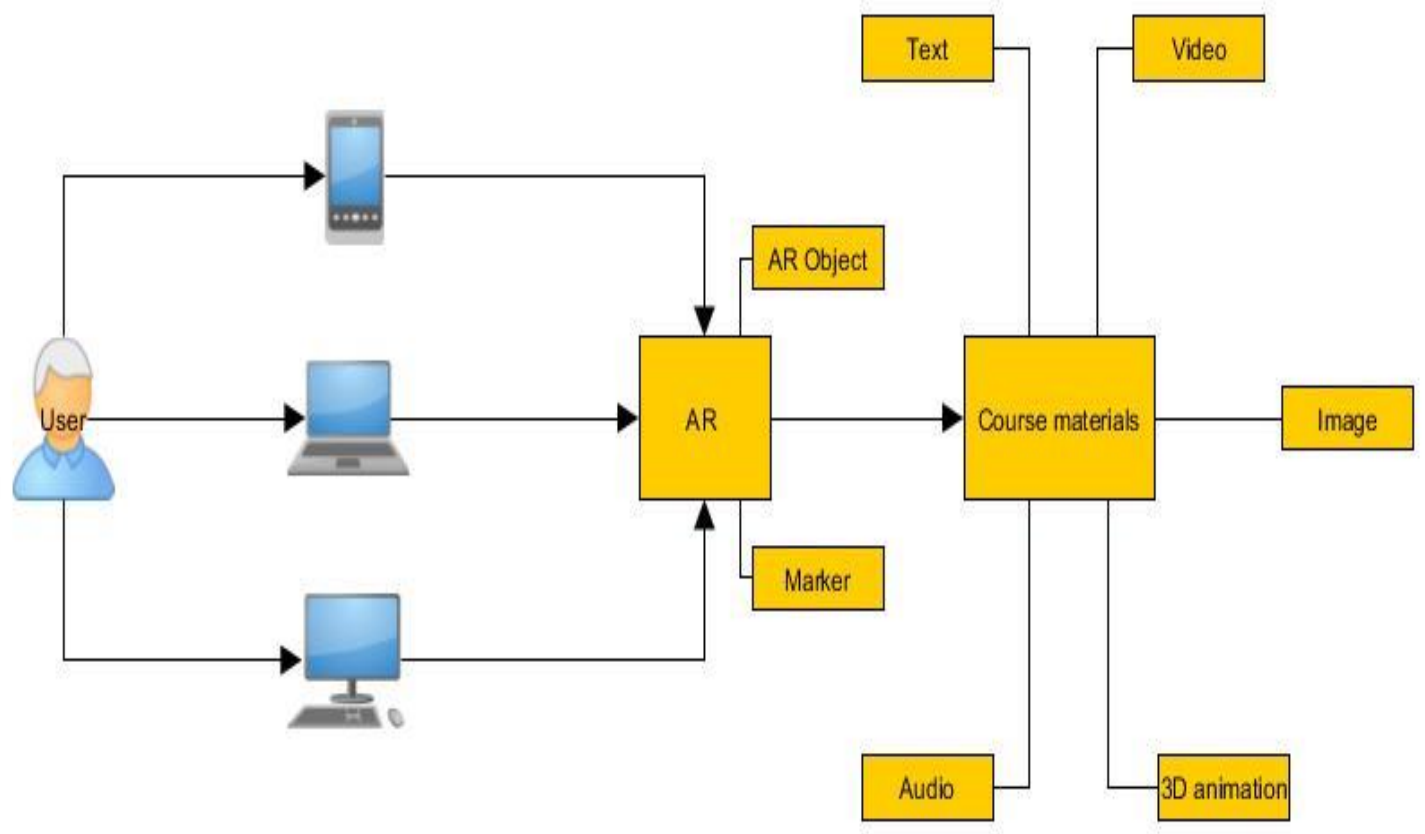

Fig. 9.A novel model of E-Government learning media using AR 


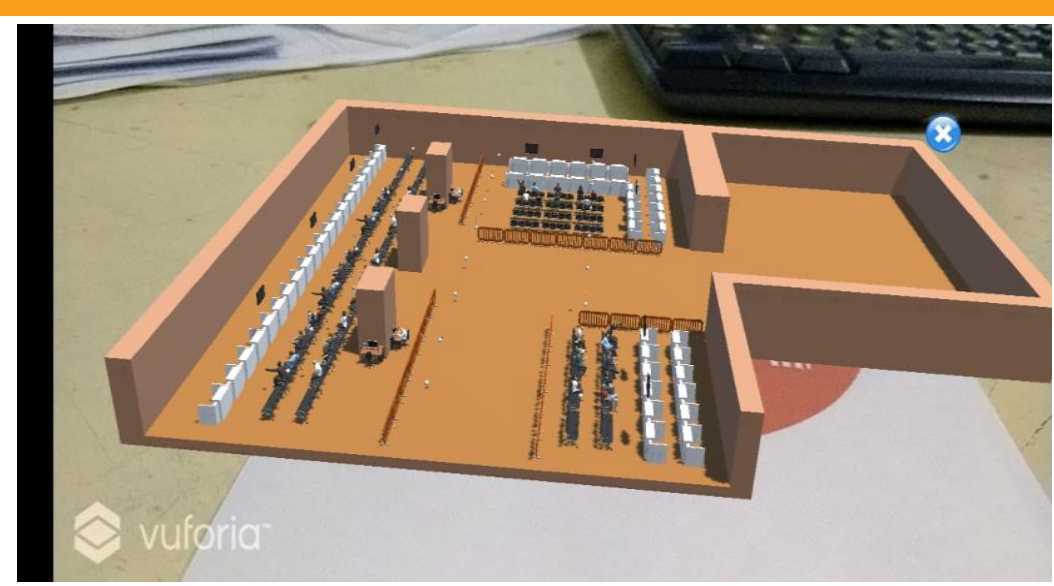

Fig. 10. Animation of Public Service Mall

Furthermore, visiting the command centre is not straightforward process as it onvolvesbureaucracy and administration process. Therefore, it is not easy for a student at information system department. Thus, AR can help students to learn about the command centre, public service mall, and other E-Government materials lecture easily and interestengly. Students need a smartphone or a computer or a laptop to install and run the application. After that, they can get the the materials in texts, video, audio, and AR animation in the application. Also, AR animation is interesting to students as the application contains video and audio. AR learning media has been changes the education approach.

This research is also compared with [20] as shown in the tabel 1. AR for E-Government learning is utilised for students in Information System and Informatics Departments. However, AR for mechanical design is used for bachelor of technology and arts et Métiers engineering students. Furthermore, this research is focused on Introduction of Data Centre and Public Service Mall. Moreover, AR for mechanical design is specified for mechanical design. Both of research have same components of text, image, video, audio, 3D animation. However, AR for E-Government learning employed AR object and marker as [20] did not mention those components. Moreover, this research utilized Softwares of Unity 2018, SketchUp, Visual Studio 2019, and Paints as another research applied Diota software. Both application also use same tablet as the hardware. However, AR for EGovernment application uses mobile phone as AR for mechanical design utilised hololens glasses.

Both applications are interesting for learners, students, and other users. AR for E-Government learning application has some contributions as follows: teacher and lecturer might change their roles as they are not only give and transfer knowledge, but also facilitate knowledge transfer. Also, Students will change their learning behaviour more independently and able to learn the course materials everywhere and everytime. Furthermore, AR for mechanical design also has contributions, such as supporting the kinematic reading and movement transformations detection in context, specified information at the appropriate moment and location, and helping in the follow-up of procedures, such as handling operations or assembling/disassembling operations shown in Table 1.

\section{Conclusion}

In conclusion, AR has proven to be one of the tools in the other sectors of the economy and has a lot to offer to E- in the future. There are some advantages to teach E-Government using AR technology, i.e., interesting, attractive, easy to use. However, there are also some limitations, AR needs a smart phone, a computer, or a laptop and its literacy for the user. A new model describes main components based on this project, i.e., user, devices, AR, and, course materials.

Additionally, there are also sub-components of the novel model, such as a smartphone, a laptop, a personal computer, AR object, marker, text, image, video, and audio. This work has some implications for theory and practice. For theory, it adds a model of learning media for e-government course and extends the body of knowledge for e-government and augmented reality fields. For practice, the augmented reality application as an outcome of this project can be utilized for e- 
Government courses. The next research will develop a virtual reality technology for e-government learning media.

Table.1 Comparison AR for E-Government learning and Mechanical Design

\begin{tabular}{|c|c|c|}
\hline $\begin{array}{l}\text { Material } \\
\text { Courses }\end{array}$ & AR for E-Government learning & AR for Mechanical Design [20] \\
\hline \multirow[t]{2}{*}{ Students } & Information System students & Bachelor of Technology Students \\
\hline & Informatics students & Arts et Métiers engineering students \\
\hline Topics & $\begin{array}{c}\text { Introduction of Data centre and Public Service } \\
\text { Mall }\end{array}$ & Mechanical Design \\
\hline \multirow[t]{7}{*}{ Components } & AR Object & Text \\
\hline & Marker & Image \\
\hline & Text & Video \\
\hline & Image & Audio \\
\hline & Video & 3D animation \\
\hline & Audio & \\
\hline & 3D animation & \\
\hline \multirow[t]{3}{*}{ Software } & Unity 2018 & Diota Software \\
\hline & SketchUp, & \\
\hline & $\begin{array}{l}\text { Visual Studio 2019, } \\
\text { Paint }\end{array}$ & \\
\hline \multirow[t]{2}{*}{ Hardware } & Tablet & Tablet \\
\hline & Mobile Phone & Hololens Glasses \\
\hline \multirow{5}{*}{$\begin{array}{c}\text { Contribution } \\
\text { of AR }\end{array}$} & Interesting & Interesting \\
\hline & Teacher and lecturer might change their roles as & Support the kinematic reading and movement \\
\hline & $\begin{array}{l}\text { but also facilitate knowledge transfer. } \\
\text { Students will change their learning behaviour }\end{array}$ & $\begin{array}{c}\text { Specified information at the appropriate moment } \\
\text { and location }\end{array}$ \\
\hline & more independently & Helping in the follow-up of procedures, such as \\
\hline & $\begin{array}{l}\text { AR application makes students able to learn the } \\
\text { course materials everywhere and everytime }\end{array}$ & $\begin{array}{c}\text { handling operations or assembling/disassembling } \\
\text { operations. }\end{array}$ \\
\hline
\end{tabular}

\section{Acknowledgment}

This work is supported by University of Trunojoyo Madura, Indonesia under Learning Innovation Award. Therefore, we woud like to thank University of Trunojoyo Madura, Indonesia for supporting this project.

\section{References}

[1] Å. Grönlund and T. A. Horan, "Introducing e-gov: history, definitions, and issues," Commun. Assoc. Inf. Syst., vol. 15, no. 1, p. 39, 2005.

[2] M. P. Rodríguez Bolívar, L. Alcaide Muñoz, and A. M. López Hernández, "Trends of e-government research: Contextualization and research opportunities," 2010.

[3] J. L. T. Blank, "Measuring the performance of local administrative public services," BRQ Bus. Res. Q., vol. 21, no. 4, pp. 251-261, 2018.

[4] B. Cuadrado-Ballesteros, I. M. García-Sánchez, and J. M. Prado-Lorenzo, "Effects of different modes of local public services delivery on quality of life in Spain," J. Clean. Prod., vol. 37, pp. 68-81, 2012, doi: 10.1016/j.jclepro.2012.06.008.

[5] T. K. Harahap, "Ethics Green Open Space Public Service by Government Pekanbaru City," ProcediaSocial Behav. Sci., vol. 211, pp. 945-952, 2015.

[6] J. Holgersson and F. Karlsson, "Public e-service development: Understanding citizens' conditions for participation," Gov. Inf. Q., 2014, doi: 10.1016/j.giq.2014.02.006.

[7] I. Lindgren and G. Jansson, "Electronic services in the public sector: A conceptual framework," Gov. Inf. Q., vol. 30, no. 2, pp. 163-172, 2013.

[8] A. Scupola and A. Zanfei, "Governance and innovation in public sector services: The case of the digital library," Gov. Inf. Q., vol. 33, no. 2, pp. 237-249, 2016.

[9] O. R. Ashaye and Z. Irani, "The role of stakeholders in the effective use of e-government resources in public services," Int. J. Inf. Manage., vol. 49, pp. 253-270, 2019. 
[10] M.-D. Guillamón, A.-M. Ríos, B. Gesuele, and C. Metallo, "Factors influencing social media use in local governments: The case of Italy and Spain," Gov. Inf. Q., vol. 27, no. March, pp. 244-260, 2016, doi: 10.1016/j.giq.2016.06.005.

[11]F. Arici, P. Yildirim, Ş. Caliklar, and R. M. Yilmaz, "Research trends in the use of augmented reality in science education: Content and bibliometric mapping analysis," Comput. Educ., vol. 142, p. 103647, 2019.

[12] J. Cabero-Almenara, J. M. Fernández-Batanero, and J. Barroso-Osuna, "Adoption of augmented reality technology by university students," Heliyon, vol. 5, no. 5, p. e01597, 2019.

[13]C. H. Chen, C.-H. Ho, and J.-B. Lin, "The development of an augmented reality game-based learning environment," Procedia-Social Behav. Sci., vol. 174, no. 1, pp. 216-220, 2015.

[14]F. Ferrati and J. A. Erkoyuncu, "Developing an augmented reality based training demonstrator for manufacturing cherry pickers," 2019.

[15]D. Fonseca, N. Martí, E. Redondo, I. Navarro, and A. Sánchez, "Relationship between student profile, tool use, participation, and academic performance with the use of Augmented Reality technology for visualized architecture models," Comput. Human Behav., vol. 31, pp. 434-445, 2014.

[16] A. Iftene and D. Trandabăț, "Enhancing the attractiveness of learning through Augmented Reality," Procedia Comput. Sci., vol. 126, pp. 166-175, 2018.

[17] T. Masood and J. Egger, "Augmented reality in support of Industry 4.0-Implementation challenges and success factors," Robot. Comput. Integr. Manuf., vol. 58, pp. 181-195, 2019.

[18] G. Mylonas, C. Triantafyllis, and D. Amaxilatis, "An augmented reality prototype for supporting IoTbased educational activities for energy-efficient school buildings," Electron. Notes Theor. Comput. Sci., vol. 343, pp. 89-101, 2019.

[19]D. Nincarean, M. B. Alia, N. D. A. Halim, and M. H. A. Rahman, "Mobile Augmented Reality: the potential for education," Procedia-social Behav. Sci., vol. 103, no. 0, pp. 657-664, 2013.

[20]D. Scaravetti and D. Doroszewski, "Augmented Reality experiment in higher education, for complex system appropriation in mechanical design," Procedia CIRP, vol. 84, pp. 197-202, 2019.

[21] S. R. Sorko and M. Brunnhofer, "Potentials of augmented reality in training," Procedia Manuf., vol. 31, pp. 85-90, 2019. 